\title{
The Factors Affecting Faculty of Sport Sciences Students' Attitudes towards Sports
}

\author{
Halil Evren Şentürk \\ Department of Physical Education and Sports Teaching, Faculty of Sport Sciences,Muğla Sitkı Koçman University, Turkey
}

Copyright $(2019$ by authors, all rights reserved. Authors agree that this article remains permanently open access under the terms of the Creative Commons Attribution License 4.0 International License

\begin{abstract}
Many young student-athletes living in Turkey prefer Faculties of Sport Sciences in various universities for their academic, sports and vocational career developments. In this process, attitudes towards sports of student-athletes gain importance. In this context, the purpose of the present research is studying the factors affecting the Faculty of Sport Sciences students' attitudes towards sports. The population consists of all undergraduate students studying at Faculties of Sports Sciences of various universities. The sample group consists of 842 students (Avg.age $=21,49 \pm 3,18$ ) from each department and each undergraduate level. "Attitude towards Sport Scale (ATSS)" developed by Şentürk and "University Life Scale (ULS)" developed by Aladağ et al. were used as the data collection tools and the scale was applied on electronic environment on participants. The data, which were found reliable (ATSS $\alpha=0,873$; ULS $\alpha=0,831$ ), were tested as normal with Kolmogorov - Smirnov test $(\mathrm{p}>, 05)$, and so were suitable for parametric tests. Accordingly, independent samples t-test and one-way variance analysis were used for comparison analyses and Pearson correlation test was used for correlation analyses. It was found that, freshman students, especially the evening education students of Coaching Education department, had significantly more positive attitudes towards sports. The most prominent finding of the research was that the attitudes towards sports decreased as the grade levels and ages of the students increased. In addition, attitudes towards the sport decrease as the students' adaptation to the university environment, academic life and social life increased. Supporting these findings with a qualitative study by means of interviewing on the same subject will provide an exploratory study on the decrease in attitude towards the sport as the age increases.
\end{abstract}

Keywords Sport, Attitude, Student, Life, University

\section{Introduction}

Physical activity refers to all of the exercises, games and daytime activities performed during the day, that occur with energy expenditure using muscles and joints and increase the heart and respiration rate and results in fatigue of different intensities [1]. Baltacı and Düzgün [2] describe physical activity as energy expenditure for energy balance and weight control.

Akgün [3] simply defines the concept of sport as the body of movements that develops individuals' health status, physical ability and performance. Talimciler [4] defines is as one of the educational and entertaining social practices that is done individually or as a group in accordance with certain rules and develops physical and mental abilities in general [4].

Sports and physical activity attract the attention of a large amount of people and are regarded as symbols of health. But these concepts are changing and developing day by day. In popular culture, sport is taken within the framework of health, entertainment and leisure activities. It represents a social, political and economic area for not only the performer but also the audience [5], and is both an instrument for health and vitality and a great economic sector [6].

In this context, basic issues, such as how inclined the individuals are to doing sports, their perspectives of sports, sport habits, and how they can train their character through sports, in short the attitudes towards sport should be questioned. In 1968, Kenyon [6] developed an instrument to determine the attitudes of university students towards physical activity. Kenyon conducted many studies on the subject matter and has inspired many researchers $[8,9,10$, 11 and 12] for similar studies on different individuals' and groups' attitudes towards physical activity and sports.

Considering that the students studying in Faculties of Sports Sciences where sports related higher education activities are carried out are to serve the national sports in the following years, their attitudes towards sport do not decrease and their sport culture is kept alive becomes important. It is known that nations that keep sports culture alive can turn this into opportunities in social, political and economic life [5]. Sportspeople of the future, who are to graduate from faculties with such titles as teachers, coaches, 
sport experts should also be motivated to keep sports culture at a certain level.

It has been frequently emphasized for many years in the related literature that the individuals who continue with higher education after primary and secondary education bring about many changes in emotional, social and academic fields, leaving almost all educational habits behind in these periods [13 and 14]. Individuals face many social factors that divert them from their sporting and academic career goals in the process of adapting to university life [15, 16 and 17]. The stress created by these social elements on the individuals, as well as being away from their home, hometown, the parents, siblings, and longing for them are considered as factors that increase the stress of the individual [18].

In this context, the purpose of the present research is studying the factors affecting the attitudes towards sports among students, who studied at Faculties of Sport Sciences of various universities in Turkey in 2017-2018 Academic Year.

\section{Method}

The present research is a descriptive study using the stratified sampling model and the survey technique from the quantitative research methods. The population consists of all undergraduate students studying at Sports Sciences Faculties of various universities in Turkey. The sample group consists of 841 students (Avg. age $=21,47 \pm 2,62$ ) from each department and each undergraduate level (Table 1). "Attitude Towards Sport Scale (ATSS)" developed by Şentürk [1] and "University Life Scale (ULS)" developed by Aladağ et al. [13] were used as the data collection tools and the scale was applied on electronic environment on participants. Students, who voluntarily participated in the survey, were contacted through social media or online communication groups. The questionnaire distributed in the electronic environment was closed to the data input because sufficient sample size was reached in about ten days.

On ATSS, the participants can get the highest score of 120 points and the lowest score of 25 points on the 5 -point Likert type scored 25 items. It is evaluated as that higher the scores from the scale indicate more positive attitude of the participants towards the sport. In the statistical analysis of the research, the participant's attitude and sub-scales (interest in sport, living with sport, doing sport actively) scores of each participant were calculated with a value between 1 and 5 , and the mean values were compared on tables.

On ULSS, the participants can get the highest score of 336 points and the lowest score of 48 points on the 7 -point Likert type scored 48 items. It is evaluated as that higher the scores from the scale indicate higher adaptation of the participants to university life. In the statistical analysis of the research, the participant's adaptation and sub-scales (adaptation to university environment, emotional harmony, personal harmony, academic harmony, social harmony, relations with opposite sex) scores of each participant were calculated with a value between 1 and 7 , and the mean values were compared on tables.

The data, which were found reliable (ATSS $\alpha=0,873$; ULS $\alpha=0,831$ ), were tested as normal with Kolmogorov Smirnov test ( $p>, 05)$, and so were suitable for parametric tests. Accordingly, independent samples t-test and one-way variance analysis were used for comparison analyses and Pearson correlation test was used for correlation analyses.

Table 1. Distribution of participant students by gender, grade, department and education type

\begin{tabular}{|c|c|c|c|c|c|c|c|c|c|c|c|c|c|c|c|}
\hline \multirow{3}{*}{$\begin{array}{l}\text { Dept. } \\
\text { Grade }\end{array}$} & \multirow{2}{*}{\multicolumn{2}{|c|}{$\begin{array}{c}\text { PES } \\
\text { Teaching }\end{array}$}} & \multicolumn{4}{|c|}{ Coach Training } & \multicolumn{4}{|c|}{ Sports Management } & \multicolumn{4}{|c|}{ Recreation } & \multirow[b]{3}{*}{ Total } \\
\hline & & & \multicolumn{2}{|c|}{ ME } & \multicolumn{2}{|c|}{$\mathbf{E E}$} & \multicolumn{2}{|c|}{ ME } & \multicolumn{2}{|c|}{ EE } & \multicolumn{2}{|c|}{ ME } & \multicolumn{2}{|c|}{ EE } & \\
\hline & $\mathrm{M}$ & $\mathrm{F}$ & $\mathrm{M}$ & $\mathrm{F}$ & $\mathrm{M}$ & $\mathrm{F}$ & M & $\mathrm{F}$ & $\mathrm{M}$ & $\mathrm{F}$ & M & $\mathrm{F}$ & M & $\mathrm{F}$ & \\
\hline 1 & 7 & 22 & 17 & 5 & 7 & 8 & 9 & 8 & 14 & 14 & 10 & 16 & 21 & 4 & 162 \\
\hline 2 & 23 & 7 & 25 & 13 & 18 & 7 & 13 & 9 & 13 & 11 & 15 & 11 & 12 & 19 & 196 \\
\hline 3 & 17 & 24 & 28 & 21 & 23 & 17 & 27 & 17 & 19 & 7 & 15 & 15 & 18 & 14 & 262 \\
\hline 4 & 9 & 4 & 17 & 14 & 11 & 19 & 13 & 14 & 17 & 15 & 7 & 4 & 8 & 8 & 160 \\
\hline $5+$ & 6 & 1 & 3 & 1 & 6 & 4 & 3 & 8 & 8 & 1 & 1 & 11 & 5 & 3 & 61 \\
\hline Total & 62 & 58 & 90 & 54 & 65 & 55 & 65 & 56 & 71 & 48 & 48 & 57 & 64 & 48 & 841 \\
\hline
\end{tabular}

Dept.: Department; PES: Physical Education and Sports; ME: Mainstream Education; EE: Evening Education; F: Female; M: Male 


\section{Findings}

In this part, the findings obtained with the present research conducted to study attitudes towards sports of the students, who studied at Sport Sciences Faculties in 2017-2018 Academic Year, in terms of different variables are presented. For the analysis of the data collected with data collection tools, scores of the participants from attitudes towards sport and the university life scales and their sub-scales will be studied in terms of different variables.
Participants' attitudes towards sport scale score averages are compared in terms of gender and education type variables in Table 2. According to the average attitude toward the sport representing the one-factor structure of the scale, there are significant differences in terms of gender and education type variables. Male and evening education students have more positive attitudes toward sport than female and mainstream students. According to the multi-factor structure of the scale, there is a significant difference in terms of living with sport sub-scale in favor of evening education and male students.

Table 2. Comparison of attitudes towards sports in terms of gender and education type

\begin{tabular}{|c|c|c|c|c|c|c|c|c|}
\hline Scale / Sub Scale & Variable & Group & $\mathbf{N}$ & $\mathbf{M}$ & St. d. & $\mathbf{t}$ & df & $\mathbf{p}$ \\
\hline \multirow{4}{*}{ Attitudes towards Sport Scale } & \multirow{2}{*}{ Gender } & Male & 465 & 4,135 & ,390 & \multirow{2}{*}{4,756} & \multirow{2}{*}{839} & \multirow{2}{*}{, $00 *$} \\
\hline & & Female & 376 & 4,005 & ,401 & & & \\
\hline & \multirow{2}{*}{ Education Type } & Mainstream & 490 & 4,018 & ,442 & \multirow{2}{*}{$-5,107$} & \multirow{2}{*}{839} & \multirow{2}{*}{, $00 *$} \\
\hline & & Evening & 351 & 4,159 & ,315 & & & \\
\hline \multirow{4}{*}{$\begin{array}{l}\text { Interest in Sport } \\
\text { Sub Scale }\end{array}$} & \multirow{2}{*}{ Gender } & Male & 465 & 4,592 & ,281 & \multirow{2}{*}{1,507} & \multirow{2}{*}{839} & \multirow{2}{*}{,13 } \\
\hline & & Female & 376 & 4,563 & ,272 & & & \\
\hline & \multirow{2}{*}{ Education Type } & Mainstream & 490 & 4,656 & ,194 & \multirow{2}{*}{10,058} & \multirow{2}{*}{839} & \multirow{2}{*}{, $00 *$} \\
\hline & & Evening & 351 & 4,471 & 34 & & & \\
\hline \multirow{4}{*}{$\begin{array}{l}\text { Living with Sport } \\
\text { Sub Scale }\end{array}$} & \multirow{2}{*}{ Gender } & Male & 465 & 3,937 & ,591 & \multirow{2}{*}{4,349} & \multirow{2}{*}{839} & \multirow{2}{*}{, $00 *$} \\
\hline & & Female & 376 & 3,730 & ,784 & & & \\
\hline & \multirow{2}{*}{ Education Type } & Mainstream & 490 & 3,734 & ,748 & \multirow{2}{*}{$-5,574$} & \multirow{2}{*}{839} & \multirow{2}{*}{, $00 *$} \\
\hline & & Evening & 351 & 3,999 &, 569 & & & \\
\hline \multirow{4}{*}{$\begin{array}{l}\text { Doing Sport Actively } \\
\text { Sub Scale }\end{array}$} & \multirow{2}{*}{ Gender } & Male & 465 & 3,453 & ,886 & \multirow{2}{*}{3,831} & \multirow{2}{*}{839} & \multirow{2}{*}{, $00 *$} \\
\hline & & Female & 376 & 3,208 & ,959 & & & \\
\hline & \multirow{2}{*}{ Education Type } & Mainstream & 490 & 3,073 & 1,075 & \multirow{2}{*}{$-10,623$} & \multirow{2}{*}{839} & \multirow{2}{*}{, $00 *$} \\
\hline & & Evening & 351 & 3,721 & ,451 & & & \\
\hline
\end{tabular}

Table 3. Comparison of attitudes towards sports in terms of department variable

\begin{tabular}{|c|c|c|c|c|c|c|}
\hline Scale / Sub Scale & Department & $\mathbf{N}$ & $\mathbf{M}$ & St. d. & $\mathbf{F}$ & $\mathbf{p}$ \\
\hline \multirow{4}{*}{ Attitudes towards Sport Scale } & 1. PES Teaching & 120 & 4,055 & ,430 & \multirow{4}{*}{19,048} & \multirow{4}{*}{, $00 *$} \\
\hline & 2. Coach Training & 264 & 4,184 & ,357 & & \\
\hline & 3. Sport Management & 240 & 3,931 & ,358 & & \\
\hline & 4. Recreation & 217 & 4,119 & ,428 & & \\
\hline \multirow{4}{*}{$\begin{array}{l}\text { Interest in Sport } \\
\text { Sub Scale }\end{array}$} & 1. PES Teaching & 120 & 4,684 & 195 & \multirow{4}{*}{86,980} & \multirow{4}{*}{, $00 *$} \\
\hline & 2. Coach Training & 264 & 4,641 & ,193 & & \\
\hline & 3. Sport Management & 240 & 4,367 & ,331 & & \\
\hline & 4. Recreation & 217 & 4,680 & ,200 & & \\
\hline \multirow{4}{*}{$\begin{array}{l}\text { Living with Sport } \\
\text { Sub Scale }\end{array}$} & 1. PES Teaching & 120 & 3,694 & ,759 & \multirow{4}{*}{20,180} & \multirow{4}{*}{, $00 *$} \\
\hline & 2. Coach Training & 264 & 4,109 &, 580 & & \\
\hline & 3. Sport Management & 240 & 3,740 & ,654 & & \\
\hline & 4. Recreation & 217 & 3,721 & ,730 & & \\
\hline \multirow{4}{*}{$\begin{array}{l}\text { Doing Sport Actively } \\
\text { Sub Scale }\end{array}$} & 1. PES Teaching & 120 & 3,358 & 1,088 & \multirow{4}{*}{2,324} & \multirow{4}{*}{, $04^{*}$} \\
\hline & 2. Coach Training & 264 & 3,463 & 9001 & & \\
\hline & 3. Sport Management & 240 & 3,281 & 830, & & \\
\hline & 4. Recreation & 217 & 3,219 & ,954 & & \\
\hline
\end{tabular}


For the doing sport actively sub-scale, there are significant differences in favor of male and evening education students. According to the obtained findings, these differences are significant at $\mathrm{p}<, 05$ level.

Table 3 presents the comparison attitudes towards sports between students of different departments and the results of the analysis conducted to find out whether there are significant differences between departments. According to the comparison of the scores from attitudes towards sport scale and its sub-scales, average scores of Sport Management departments students are significantly lower at $\mathrm{p}<, 05$ level than students of other departments. Especially Recreation department students' average scores from doing sport actively sub-scale are much lower than other students. On the other hand, Coach Training department students have higher average scores in this sub-scale than students of other departments.

Table 4 presents the comparison attitudes towards sports between students of different grades and the results of the analysis conducted to find out whether there are significant differences between grades. According to the comparison of the scores from attitudes towards sport scale and its sub-scales, average scores of $4^{\text {th }}$ grade students and students, who have been studying at least for 5 years, are significantly lower at $\mathrm{p}<, 05$ level. Especially average scores of students, who have been studying at least for 5 years, from doing sport actively sub-scale are much lower than other students. On the other hand, $1^{\text {st }}$ grade students have higher average scores in this sub-scale than other students.

The correlations between participants in terms of grade, age, scale total score, and sub-scale scores are presented in Table 5. Accordingly, there are significant positive correlations between the whole scale and its sub-scales. The most prominent findings from the correlation analysis are the negative correlations between grade and age variables and doing sport actively sub-scale.

Some of the correlations between attitude towards scale, university life scale and sub-scales of these and grade and age variables are significant at $p<, 05$ level (Table 5).

Table 4. Comparison of attitudes towards sports in terms of grade variable

\begin{tabular}{|c|c|c|c|c|c|c|}
\hline Scale / Sub Scale & Grade & $\mathbf{N}$ & $\mathbf{M}$ & St. d. & $\mathbf{F}$ & $\mathbf{p}$ \\
\hline \multirow{5}{*}{ Attitudes towards Sport Scale } & $1^{\text {st }}$ & 162 & 4,387 & ,394 & \multirow{5}{*}{78,584} & \multirow{5}{*}{, $00 *$} \\
\hline & $2^{\text {nd }}$ & 196 & 4,232 & ,266 & & \\
\hline & $3^{\text {rd }}$ & 262 & 3,972 & ,291 & & \\
\hline & $4^{\text {th }}$ & 160 & 3,869 & ,364 & & \\
\hline & $5+$ & 61 & 3,747 &, 509 & & \\
\hline \multirow{5}{*}{$\begin{array}{l}\text { Interest in Sport } \\
\text { Sub Scale }\end{array}$} & $1^{\text {st }}$ & 162 & 4,727 & ,365 & \multirow{5}{*}{49,912} & \multirow{5}{*}{, $00 *$} \\
\hline & $2^{\text {nd }}$ & 196 & 4,681 & ,261 & & \\
\hline & $3^{\text {rd }}$ & 262 & 4,557 & ,205 & & \\
\hline & $4^{\text {th }}$ & 160 & 4,421 & ,159 & & \\
\hline & $5+$ & 61 & 4,364 & ,197 & & \\
\hline \multirow{5}{*}{$\begin{array}{l}\text { Living with Sport } \\
\text { Sub Scale }\end{array}$} & $1^{\text {st }}$ & 162 & 4,177 & ,624 & \multirow{5}{*}{23,806} & \multirow{5}{*}{, $00 *$} \\
\hline & $2^{\text {nd }}$ & 196 & 3,986 & ,445 & & \\
\hline & $3^{\text {rd }}$ & 262 & 3,726 & ,605 & & \\
\hline & $4^{\text {th }}$ & 160 & 3,697 & ,811 & & \\
\hline & $5+$ & 61 & 3,400 & ,989 & & \\
\hline \multirow{5}{*}{$\begin{array}{c}\text { Doing Sport Actively } \\
\text { Sub Scale }\end{array}$} & $1^{\text {st }}$ & 162 & 3,954 & ,872 & \multirow{5}{*}{44,453} & \multirow{5}{*}{, $00 *$} \\
\hline & $2^{\text {nd }}$ & 196 & 3,622 & ,672 & & \\
\hline & $3^{\text {rd }}$ & 262 & 3,089 & ,694 & & \\
\hline & $4^{\text {th }}$ & 160 & 2,964 & 1,004 & & \\
\hline & $5+$ & 61 & 2,917 & 1,284 & & \\
\hline
\end{tabular}


Table 5. Correlations between students' grade, age, scales scores and sub-scales scores

\begin{tabular}{|c|c|c|c|c|c|c|c|c|c|c|c|c|c|}
\hline & & 1 & 2 & 3 & 4 & 5 & 6 & 7 & 8 & 9 & 10 & 11 & 12 \\
\hline \multirow{2}{*}{ 1.Grade } & $r$ & & ,889 &,- 712 &,- 542 &,- 658 &,- 853 & ,613 & ,742 & ,853 & ,591 & ,431 & ,317 \\
\hline & $P$ & &, $000 *$ & ,032* &, $042 *$ & ,039* & ,012* & ,035* &, $019 *$ & , $002 *$ &, 075 & ,067 &, 264 \\
\hline \multirow{2}{*}{ 2.Age } & $r$ & ,889 & &,- 317 &,- 453 &,- 672 &,- 705 &, 712 & ,755 & ,811 &, 526 & ,454 & ,348 \\
\hline & $P$ &, $000 *$ & &, 064 & ,178 & ,045* &, $027 *$ & ,028* &, $023^{*}$ & ,012* & ,093 & ,098 & ,310 \\
\hline \multirow{2}{*}{$\begin{array}{l}\text { 3.Attitudes towards } \\
\text { sport }\end{array}$} & $r$ &,- 712 &,- 317 & & ,392 & ,429 & ,679 &,- 713 &,- 709 &,- 671 & ,335 &,- 321 &,- 129 \\
\hline & $P$ & ,032* & ,064 & & ,105 & ,053 &, $012 *$ & ,019* & ,031* & ,041* & ,176 & ,138 &, 215 \\
\hline \multirow{2}{*}{ 4.Interest in Sport } & $r$ &,- 542 &,- 453 & ,392 & & ,462 & ,678 &,- 373 &,- 352 &,- 198 & ,283 &,- 173 &,- 459 \\
\hline & $P$ &, $042 *$ & ,178 & ,105 & & ,089 & ,039* & ,111 & ,187 &, 576 & ,392 & ,637 & ,282 \\
\hline \multirow{2}{*}{ 5.Living with Sports } & $r$ & -658 &,- 672 & ,429 & ,462 & & 467 &,- 323 &,- 355 &,- 286 &, 456 & 397 & ,391 \\
\hline & $P$ & ,039* &, $045^{*}$ & ,053 &, 089 & & ,049* &, 078 & ,091 & ,125 &, 071 & ,109 & ,302 \\
\hline \multirow{2}{*}{ 6.Doing Sport Actively } & $r$ & -853 &,- 705 & 679 & ,678 & ,467 & & -853 &,- 726 &,- 751 &, 552 &,- 343 &,- 517 \\
\hline & $P$ &, $012 *$ &, $027 *$ &, $012 *$ & ,039* & ,049* & &, $012 *$ &, $013^{*}$ & ,024* & ,043* &, 068 & ,162 \\
\hline \multirow{2}{*}{$\begin{array}{c}\text { 7.Adaptation to } \\
\text { University } \\
\text { Environment }\end{array}$} & $r$ & ,613 & ,712 &,- 713 &,- 373 &,- 323 & -853 & & ,672 &, 712 & ,684 &, 712 & ,718 \\
\hline & $P$ & ,035* &, $028^{*}$ &, $019 *$ & ,111 &, 078 & ,012* & &, $025^{*}$ & ,037* & ,043* & ,034* & ,032* \\
\hline \multirow{2}{*}{ 8.Academic Harmony } & $r$ &, 742 & ,755 &,- 709 &,- 352 &,- 355 &,- 726 & ,672 & & ,463 & ,675 & ,617 & ,670 \\
\hline & $P$ & ,019* &, $023^{*}$ & ,031* & ,187 &, 091 & ,013* & ,025* & & ,028* &, 051 &, $029 *$ & ,013* \\
\hline \multirow{2}{*}{ 9.Social Harmony } & $r$ & ,853 & ,811 &,- 671 &,- 198 &,- 286 &,- 751 & ,712 & ,463 & & ,663 & ,733 & ,608 \\
\hline & $P$ &, $002 *$ &, $012 *$ &, $041^{*}$ &, 576 & ,125 & ,024* & ,037* &, $028^{*}$ & &, $040^{*}$ & ,038* &, $049 *$ \\
\hline \multirow{2}{*}{ 10.Personal Harmony } & $r$ &, 591 &, 526 & ,335 & ,283 & ,456 &, 552 & ,684 & ,675 & ,663 & & 463 & ,795 \\
\hline & $P$ & ,075 & ,093 & ,176 & ,392 & ,071 & ,043* & ,043* & 051 &, $040 *$ & & ,039* & ,016* \\
\hline \multirow{2}{*}{$\begin{array}{l}\text { 11.Relations with } \\
\text { Opposite Sex }\end{array}$} & $r$ & ,431 & ,454 &,- 321 &,- 173 & ,397 &,- 343 &, 712 & ,617 & ,733 & ,463 & & ,613 \\
\hline & $P$ &, 067 & ,098 & ,138 & ,637 & ,109 &, 068 & ,034* &, $029 *$ & ,038* & ,039* & &, $041^{*}$ \\
\hline \multirow{2}{*}{ 12.Emotional Harmony } & $r$ & ,317 & ,348 &,- 129 &,- 459 & ,391 &,- 517 &, 718 & ,670 & ,608 & ,795 & ,613 & \\
\hline & $P$ & ,264 & ,310 & ,215 & ,282 & ,302 & ,162 & ,032* &, $013 *$ & ,049* & ,016* &, $041^{*}$ & \\
\hline
\end{tabular}

${ }^{*} \mathrm{p}<, 05$

\section{Discussion and Conclusions}

According to the data collected from Faculties of Sport Sciences students, there are significant differences between male and female participants in terms of attitude towards sport. Göksel et al. [19], who reported no significant difference between male and female students in terms of attitudes towards sport, suggested that male and female students had similar perspectives of sport. In another similar study conducted on Faculty of Islamic Studies students, Türkmen et al. [20], reported a significant difference across genders and that male students had more positive attitudes than female students. Yanık [21], in his research, found that female students' attitude averages were lower than male students who had more positive attitudes.

According to the findings related to the relations between attitudes towards sports and different education types, attitudes towards sport and doing sport actively scores of evening education students are higher than mainstream students. The reason for this finding might be that evening education students can continue their active sport lives during the day, while they have classes during evening time. The related literature doesn't include any studies on the relationship between university students' education type and physical activity and physical education and sports.

Coach Training department students have more positive attitudes towards sports than other students, which can be explained with the fact that doing sport actively attitudes of these students are also high. Coach Training department select their students on a more performance-based criteria in talent examinations, which is believed to increase these students doing sport actively attitudes and accordingly attitudes toward sports. Göksel et al. [19] also reported a significant difference in attitudes towards sports between students of Coach Training department and Physical Therapy and Rehabilitation department and Nutrition and Dietetics department. In terms of the living with sport sub-scale, a significant difference in favor of Physical Therapy and Rehabilitation department students was reported.

Negative correlations were found between students' attitudes towards sports, and sub-scales in terms of grade and age variables. Accordingly, as grades and ages of students increase, their attitudes towards sport scores 
decrease. It was found that this finding was resulted from that after students get into school, they end their active sport lives partially for difference reasons.

As students' adaptation to university environment, academic harmony and social harmony increase, their attitudes towards sport scores decrease. According to the analysis results, these correlations were negative and significant at $\mathrm{p}<, 05$ level.

Consequently, it was found that freshman students of Faculties of Sport Sciences of various universities, especially the evening education students of Coaching Education department, had significantly more positive attitudes towards sports. The most prominent finding of the research was that the attitudes towards sports decreased as the grade levels and ages of the students increased. In addition, attitudes towards the sport decrease as the students' adaptation to the university environment, academic life and social life increased. Supporting these findings with a qualitative study by means of interviewing on the same subject will provide an exploratory study on the decrease in attitude towards the sport as the age increases.

\section{REFERENCES}

[1] Şentürk, H. E. (2014). Spora yönelik tutum ölçeği: geliştirilmesi, geçerliliği ve güvenirliği. CBÜ Beden Eğitimi ve Spor Bilimleri Dergisi, 7(2), 8-18.

[2] Baltac1, G. \& Düzgün, İ. (2008). Adolesan ve Egzersiz. Sağlık Bakanlığı Yayın No: 730

[3] Akgün, N. (1992). Spor hekimliği kavramı. içinde: Ergen E (ed). Spor Hekimliği. Ankara: Maya Matbaacılık Yayıncılık Ltd. Şti., 1-3.

[4] Talimciler, A. (2008). Futbol Değil İș: Endüstriyel Futbol. İletişim Kuram ve Araştırma Dergisi, Sayı 26, Sayfa 89-114.

[5] Solmaz, B. \& Aydın, B.O. (2012). "Popüler Kültür ve Spor Merkezlerine Yönelik Bir Araștırma" Gümüșhane Üniversitesi İletişim Fakültesi Elektonik Dergisi, Cilt 1, Say1 4, 67-82

[6] Yetim, A. (2000). Sosyoloji ve Spor, Topkar Matbaacılık, Ankara.

[7] Kenyon, G. S. (1968). Six scales for assessing attitude toward physical activity. Research Quarterly. American Association for Health, Physical Education and Recreation, 39(3), 566-574.

[8] Biddle, S. \& Mutrie, N. (1991). Psychology of physical activity and exercise. Psychology of physical activity and exercise.

[9] Eysenck, H. J., Nias, D. K. \& Cox, D. N. (1982). Sport and personality. Advances in behaviour research and therapy, $4(1), 1-56$

[10] Mathes, S. A. \& Battista, R. (1985). College men’s and women's motives for participation in physical activity. Perceptual and Motor Skills, 61(3), 719-726.

[11] Schutz, R. W., Smoll, F. L., Carre, F. A. \& Mosher, R. E. (1985). Inventories and norms for children's attitudes toward physical activity. Research Quarterly for exercise and sport, 56(3), 256-265.

[12] Subramaniam, P. R. \& Silverman, S. (2000). Validation of scores from an instrument assessing student attitude toward physical education. Measurement in Physical Education and Exercise Science, 4(1), 29-43.

[13] Aladă̆, M., Kağnıcı, D.Y., Tuna, M.E. ve Tezer, E. (2003). Üniversite Yaşamı Ölçeği: ölçek geliştirme ve yap1 geçerliliği üzerine bir çalışma. Türk Psikolojik Danışma ve Rehberlik Dergisi, 2(20), 41-47.

[14] Martin, L. M. (2000). The Relationship of College Experiences to Psychological Outcomes in Students. Journal of College Student Development, 41, 293-301.

[15] Tuna, M. E. (2003). Cross-cultural differences in coping strategies as predictors of university adjustment of Turkish and US Students. Yayınlanmamış doktora tezi, Ortadoğu Teknik Üniversitesi, Ankara.

[16] Credé, M., ve Niehorster, S. (2012). Adjustment to college as measured by the student adaptation to college questionnaire: A quantitative review of its structure and relationships with correlates and consequences. Educational Psychology Review, 24(1), 133-165.

[17] Amanvermez, Y (2015). Üniversite Birinci Sınıf Öğrencilerinin Üniversite Yaşamına Uyumlarının Güvengenlik ve Öğrenilmiş Güçlülük Düzeylerine Göre Yordanmas1. Yayınlanmamış Yüksek Lisans Tezi, Ege Üniversitesi, Sosyal Bilimler Enstitüsü, Rehberlik ve Psikolojik Danışmanlık Bilim Dalı, İZMİR.

[18] Wintre, M. G., ve Yaffe, M. (2000). First-year students' adjustment to university life as a function of relationships with parents. Journal of Adolescent Research, 15(1), 9-37.

[19] Göksel, A.G., Caz, Ç., Yazıcı, Ö.F., İkizler, H.C. (2017) Farklı Bölümlerdeki Öğrencilerin Spora Yönelik Tutumlarının Karşılaştırılması: Marmara Üniversitesi Örneği. Spor ve Performans Araştırmaları Dergisi ;8(2)

[20] Türkmen, M., Abdurahimoğlu, Y., Varol, S., Gökdağ, M. (2016). İslami İlimler Fakültesi Öğrencilerinin Spora Yönelik Tutumlarının İncelenmesi (Bartın Üniversitesi Örneği). International Journal of Contemporary Educational Studies (IntJCES) June: 2 (1).

[21] Yanik, M. (2018). Attitudes of University Students Towards Sport. Journal of Education and Training Studies ; 6(5), 111-117. 